\title{
RISK OF RETURN CHARACTERISTICS OF ISLAMIC BANK FINANCING PORTFOLIO IN INDONESIA
}

\author{
Zamzam Habibi ${ }^{a}$ \\ Sulistya Rusgianto ${ }^{b}$ \\ a,b Islamic Economics Department, Faculty of Economics and Business, University of Airlangga \\ zamzamhabibi1404@gmail.com ${ }^{\text {a }}$; sulistya@feb.unair.ac.id ${ }^{\text {b }}$
}

\section{ARTICLE HISTORY}

Received:

13 January 2021

Revised

5 May 2021

Accepted:

31 May 2021

Online available:

30 June 2021

Keywords:

Islamic Bank,

Risk of Return, Return Volatility, Financing Risk, Financing Portfolio.

Correspondence:

Name:

Sulistya Rusgianto

Email:

sulistya@feb.unair.ac.id

\section{ABSTRACT}

The study aims to investigate the risk of return characteristics of Islamic bank financing portfolios. A quantitative approach of value at risk is used to estimate return volatility of Islamic commercial banks and Islamic business units in Indonesia for the period of May 2014 to June 2020. The finding suggests proportion of equity-based financing tends to increase in contrast to decreasing of debt and lease-based financing. While rate of return for all financing types tends to decline, the return of equity-based financing experiences higher volatility than other two financing types. The main finding regarding the decrease in value at risk indicates Islamic banks able to reduce risk of financing portfolio. The finding implies Islamic banks should continue to improve the best-practice of risk management based on their past experience to anticipate future risk. As for the regulators, the finding may be used to develop early warning system to anticipate a systemic failure in Islamic banking industry. Further research is recommended to explore impact of market behavior on the risk of each type of financing.

\section{INTRODUCTION}

Risk is an inherent aspect of all things commercial, especially a credit risk of banks that is the main source of their financial balance (Masood et al., 2012). Credit risk is the potential failure of borrowers to meet obligations and is the main source of financial balance in the banking sector. According to Ahmad and Ahmad (2004), leverage, funding costs, and assets is possible to influence the credit risk of banking sector.

There are different characteristics of credit risk between Islamic banks and conventional banks. The difference mainly due to the use of sharia compliance contracts 
in the financing products (Chamberlain et al., 2020). When a conventional bank uses an interest-based loan contract, Islamic bank use various contracts such as buying-selling, leasing, and partnership. These types of contracts, that are acceptable to the public, consist of mudharabah, murabahah, musyarakah, qardh, istishna, and multi-service. The growth of these contracts has been recorded by the Indonesian Financial Authority Services/Otoritas Jasa Keuangan (OJK) in the Sharia Financial Development Report below.

Table 1

Islamic Banks' Financing based on Type of Sharia-Compliant Contract (in Billion Rupiah)

\begin{tabular}{lcccccc}
\hline \multirow{2}{*}{ Contract } & $\mathbf{7}$ & \multicolumn{7}{c}{ Year } \\
\cline { 2 - 7 } Mudharabah & $\mathbf{2 0 1 4}$ & $\mathbf{2 0 1 5}$ & $\mathbf{2 0 1 6}$ & $\mathbf{2 0 1 7}$ & $\mathbf{2 0 1 8}$ & $\mathbf{2 0 1 9}$ \\
Murabahah & 5,930 & 6,841 & 7,715 & 10,506 & 10,389 & 8,366 \\
Musyarakah & 25,504 & 28,469 & 29,473 & 35,818 & 36,671 & 37,929 \\
Qardh & 9,058 & 13,356 & 24,369 & 41,096 & 60,997 & 72,909 \\
Istishna & 708 & 642 & 847 & 872 & 826 & 841 \\
\hline
\end{tabular}

Source: Financial Authority Services (OJK, 2021)

Despite the-increasing-growth, Tariqullah and Habib (2001) mentioned that these Islamic banks' contracts are more vulnerable to various types of risk. However, disagreements were found in empirical studies comparing risks between Islamic and conventional banks. Kabir et al. (2015); Mokni et al. (2016) are argued that the Islamic banks are riskier than the conventional counterpart. In contrary, Akram and Rahman (2018); Fakhfekh et al. (2016); Ferhi (2018) are found that the conventional banks experience higher risk than the Islamic one. Therefore, studying risk characteristics of Islamic banking is still necessary.

Several studies have investigated effect of Islamic contracts on risk of return of Islamic banks. Empirical studies of Shahari et al. (2015); Warninda et al. (2019) found equity-based financing has association with return volatility of Islamic banks. Meanwhile, Chowdhury et al. (2016); Ismal $(2010,2014)$ study the effect of Islamic contracts on the financing portfolio risk. However, such researches calculate risk as a deviation from the average, not the maximum risk that may occur in a financing portfolio. Knowing the volatility and possibility of risk is very important for bank management as well as regulators. For Islamic banks, such measurement may be used to measure the resilience of banks to absorb risk that does not make the bank in the dangerous situation. Meanwhile, the regulators can use it as a measure of the banking system stability.

Therefore, this study focuses on calculating the maximum risk of financing portfolio using the value at risk approach. This approach has the advantage of combining volatility and probability in measuring the maximum risk. Although similar research has been carried out by Ismal (2010), this research differs in at least two ways. First, it uses a 
classification that is in line with the characteristics of the Islamic contract, namely equity, debt, and lease-based financing, while Ismal (2010) includes lease into debt-based financing and adds service-based financing in the financing classification. Second, this study uses latest data from May 2014 to June 2020 in which the Financial Services Authority/Otoritas Jasa Keuangan (OJK) of Indonesia changes Islamic contract classification start in May 2014. Indonesia is selected as object of the study due to it has the largest Muslim population in the world that make it very potential market for Islamic banking.

\section{LITERATURE REVIEW}

The sharia compliance contracts used in the financing products of Islamic banking can be classified into three groups namely equity, debt, and lease-based financing. The equity-based financing includes contract of mudarabah (trustee partnership), musharakah (joint venture), muzara'ah (harvest yield profit sharing), and musaqah (feebased plantation partnership on certain portion of yield). The debt-based financing consists of contract of murabahah (mark up sale), salam (deferred delivery sale), istishna (manufacture-sale), and qardh (benevolent loan). Meanwhile, ijarah (lease) and other contracts based on it are classified in lease-based financing (Ikatan Bankir Indonesia, 2018). In addition to main financing products, Islamic banks offer serviced-based financing using wakalah (use in letter of credit service), kafalah (letter of guarantee), and hiwalah (debts or liabilities transfer) (Obaidullah, 2005).

Each type of sharia compliance contracts by its nature have different characteristic, therefore they have different risk characteristic as well. For example, mudarabah and musyarakah are expected have high risk compared to other contracts due return depend on performance of business and there is possible moral hazard risk of business partners (Errico \& Sundararajan, 2002; Ferhi, 2018). The risk of debt-based financing may arise from selling objects as well as payment default of customers (Haron \& Hock, 2012; lqbal \& Mirakhor, 2011). As for ijarah contracts, the main risk is associated with rental asset and default of rental payment (Hanif, 2016). Consequently, Islamic banks should aware to these characteristics in order to mitigate the risk of financing.

A risk is usually associated with return in many ways. In finance, a return is required by investors to compensate risk of holding a financial asset. The principle of risk and return in Islam is often associated with the jurisprudence principle of al-ghunm bilghurm which means gain come with risk (Rosly \& Zaini, 2008). Furthermore, risk is a provision of Allah with uncertain conditions in the future as stated in Al-Quran surah Luqman verse 18, "Indeed, Allah [alone] has knowledge of the Hour and sends down the 
rain and knows what is in the wombs. And no soul perceives what it will earn tomorrow, and no soul perceives in what land it will die. Indeed, Allah is Knowing and Acquainted."

According to Fakhfekh et al. (2016), the calculation of financial risk could consider using volatility as a proxy. Volatility is the standard deviation of the charge in value of a financial instrument at a specific time period and is used to calculate the risk of a financial instrument over a period of time generally on an annual basis (Bank Indonesia, 2017). The impact of volatility is a very large capital loss, even with the right strategy in a targeted manner (Tan \& Lakehal-Ayat, 2018). There is a study of Grassa (2012) stated that volatility is positively related to the income of Islamic banks. Louhichi and Boujelbene (2016) then added that the volatility reached the highest level if the allocation of financing is high. These studies show that volatility reflects Islamic banks' future behavior.

The contract of musyarakah has a high level of risk to the investor partners as well as significant capital depreciation (Errico \& Sundararajan, 2002). Furthermore, in other profit sharing financing, a mudharabah contract, the risk occurs as a result of counterparty risk because of the poor performance of the partners (Ferhi, 2018). The risk of debt financing occurs in murabahah contracts due to customer default (Haron \& Hock, 2012). The various Islamic bank financing systems create different levels of risk in each financing contract. These different levels of risk make the effect of the type of contract on the risk greatly influences the financing provided by Islamic banks.

Asset allocation is the process of combining various types of assets such as in a portfolio to meet investment needs (Dewi, 2013). Sari and Purwanto (2012) explained the asset allocation policy as an action to allocate the proportion of riskless financial instruments and risky financial instruments. The allocation of Islamic bank financing assets is an important strategy in providing funds provided by Islamic banks. However, it cannot be denied that at a large level of funding allocation there is a large risk impact. Therefore, if there is a risk of default on a large financing allocation, this will greatly affect the losses faced by Islamic banks.

A risk can be measured in various ways, such as variance or standard deviation. These measures indicate deviations or volatility from the mean. However, measuring volatility alone is not enough because risks also have the possibility to occur. Therefore, combining volatility and risk occurrence possibility is very important in risk mitigation. Value at risk ( $\mathrm{VaR})$ is popular method to combine such two aspects of risk. Value at risk may be used to measure the worst expected loss that an institution can suffer over a given time interval at given confidence level (Butler, 1999). Therefore, the study employs value at risk to investigate and measure the characteristic of Islamic bank's financing portfolio. 
Value at risk has been concluded previously in the study of Ismal (2010). The research emphasize the approach to analyze the volatility of returns and expected loses of Islamic bank financing in Indonesia from the period of 2002 to the period of 2008. In his research, Ismal (2010) employed several contract that are available and welldeveloped in Islamic banking sector, namely musyarakah and mudharabah which are classified as equity-based financing; murabahah, salam, istishna, ijarah, and qardh which are grouped as debt-based financing; and service-based financing which are wakalah, kafalah, sharf, and hiwalah. Ismal (2010) then found that debt-based financing and equity-based financing have controlled risk and have a sustainable return on financing, while service-based financing is very profitable for Islamic banks.

Another empirical study had been done by Shahari et al. (2015), investigating the expected loss of sharia credit instruments in several countries' Islamic banks. They collected the annual data of assets-based financing and debt-based financing of 40 Islamic banks from 12 countries, such as Malaysia, Jordan, Sudan, Yemen, UEA, South Africa, Bangladesh, Indonesia, Bahrain, Lebanon, and Pakistan over the periods from 2005 to 2012. They categorized mudharabah and musyarakah to the assets-based financing, while debt-based financing consisted of murabahah, salam, istishna, ijarah, and tawarruk. As a result, the study found that debt-based financing instrument was more popular than assets-based financing among global Islamic banks. The study also showed that assets-based financing was less interesting even though it had lower credit risk due to lack of collateral and unsecured rate of returns.

\section{RESEARCH METHODS}

The object of the study is Islamic banking industry in Indonesia which can be classified into three categories, namely commercial banks, business unit banks, and rural banks. The study focuses on the commercial and business banks only due to it dominates Islamic bank industry in Indonesia in term of total asset and market share. The aggregate monthly data of such banks are collected from the OJK website for the period of May 2014 to June 2020.

The study follow the variance-covariance method of Butler (1999); Ismal (2010) in estimating value at risk. The function of this approach is for analysis of the volatility returns and estimated losses from funding provided the Islamic banking industry. Also, this approach has the advantage of combining volatility and probability in measuring the maximum risk. Al-Foul (2017) found that variance-covariances provide a promising alternative portfolio management. Variance-covariance technique is a construction of an internal allocation matrix composed of information on volatility and financing correlation (Shahari et al., 2015). 
The first step is to calculate the standard deviation of each type of financing groups namely equity, debt and lease-based financing using the following formula:

$$
\sigma=\sqrt{\frac{n \Sigma_{i}^{n}=_{1} x_{i}^{2}-\left(\sum_{i=1 x_{1}}^{n}\right)^{2}}{n(n-1)}}
$$

Next, the following formula is used to calculate the correlation among two financing types.

$$
\rho=\frac{\Sigma(x-\bar{x})(y-\bar{y})}{\sqrt{\Sigma(x-\bar{x})^{2}} \sqrt{\Sigma(y-\bar{y})^{2}}} \quad \ldots . .(\text { Error! No text of specified style in document.2) }
$$

Following the previous step, the variance of financing portfolio is calculated using the following equation:

$$
\begin{aligned}
& \operatorname{Var}\left(R_{p}\right)=\sum_{i=1}^{3} \sum_{j=1}^{3} w_{i} w_{j} \sigma_{i, j} \\
& =w_{1}^{2} \sigma_{1}+w_{2}^{2} \sigma_{2}+w_{3}^{2} \sigma_{3}+2 w_{1} w_{2} \rho_{1,2}+2 w_{1} w_{3} \rho_{1,3}+2 w_{2} w_{3} \rho_{2,3} \ldots .
\end{aligned}
$$

where $R p$ is a variance of bank portfolio financing; $w$ is weight of a group of bank financing; $s$ is standard deviation of a group of bank financing; and $r$ is a coefficient of correlation of two groups of bank financing. The number 1, 2, and 3 represent the equity, debt, and lease-based financing, respectively.

The next step is to calculate the portfolio volatility towards the financing of the Islamic banking industry which is the multiplication of the derivative of the standard deviation for each group of types of financing in a $3 \times 3$ matrix called the standard deviation matrix. The volatility of the portofolio calculated with confidence interval $90 \%$, 95\%, and 99\% as in Equation 4.

$$
(\alpha)\left[\begin{array}{ccc}
\sigma_{1} & 0 & 0 \\
0 & \sigma_{2} & 0 \\
0 & 0 & \sigma_{3}
\end{array}\right]=\left[\begin{array}{ccc}
\alpha \sigma_{1} & 0 & 0 \\
0 & \alpha \sigma_{2} & 0 \\
0 & 0 & \alpha \sigma_{3}
\end{array}\right]
$$

Then, a matrix is constructed by multiplying the volatility matrix and the correlation coefficient matrix as in Equation 5.

$$
\left[\begin{array}{ccc}
\alpha \sigma_{1} & 0 & 0 \\
0 & \alpha \sigma_{2} & 0 \\
0 & 0 & \alpha \sigma_{3}
\end{array}\right]\left[\begin{array}{ccc}
1 & \rho_{1,2} & \rho_{1,3} \\
\rho_{1,2} & 1 & \rho_{2,3} \\
\rho_{3,1} & \rho_{3,2} & 1
\end{array}\right]=\left[\begin{array}{ccc}
\alpha \sigma_{1} & \alpha \sigma_{1} \rho_{1,2} & \alpha \sigma_{1} \rho_{2,3} \\
\alpha \sigma_{2} \rho_{2,1} & \alpha \sigma_{2} & \alpha \sigma_{2} \rho_{2,3} \\
\alpha \sigma_{3} \rho_{3,1} & \alpha \sigma_{3} \rho_{3,2} & \alpha \sigma_{3}
\end{array}\right]
$$

Following this order, the variance-covariance matrix is developed using Equation 6. 


$$
\left[\begin{array}{ccc}
\left(\alpha \sigma_{1}\right)^{2} & \left(\alpha \sigma_{1}\right) \rho_{1,2}\left(\alpha \sigma_{2}\right) & \left(\alpha \sigma_{1}\right) \rho_{1,3}\left(\alpha \sigma_{3}\right) \\
\left(\alpha \sigma_{2}\right) \rho_{2,1}\left(\alpha \sigma_{1}\right) & \left(\alpha \sigma_{2}\right)^{2} & \left(\alpha \sigma_{2}\right) \rho_{2,3}\left(\alpha \sigma_{3}\right) \\
\left(\alpha \sigma_{3}\right) \rho_{3,1}\left(\alpha \sigma_{1}\right) & \left(\alpha \sigma_{3}\right) \rho_{3,2}\left(\alpha \sigma_{2}\right) & \left(\alpha \sigma_{3}\right)^{2}
\end{array}\right]
$$

The variance-covariance matrix of Equation 6 is weighted with the financing proportion to get a matrix in Equation 7.

$$
\left[\begin{array}{lll}
w_{1} & w_{2} & w_{3}
\end{array}\right]\left[\begin{array}{ccc}
\left(\alpha \sigma_{1}\right)^{2} & \left(\alpha \sigma_{1}\right) \rho_{1,2}\left(\alpha \sigma_{2}\right) & \left(\alpha \sigma_{1}\right) \rho_{1,3}\left(\alpha \sigma_{3}\right) \\
\left(\alpha \sigma_{2}\right) \rho_{2,1}\left(\alpha \sigma_{1}\right) & \left(\alpha \sigma_{2}\right)^{2} & \left(\alpha \sigma_{2}\right) \rho_{2,3}\left(\alpha \sigma_{3}\right) \\
\left(\alpha \sigma_{3}\right) \rho_{3,1}\left(\alpha \sigma_{1}\right) & \left(\alpha \sigma_{3}\right) \rho_{3,2}\left(\alpha \sigma_{2}\right) & \left(\alpha \sigma_{3}\right)^{2}
\end{array}\right]=\left[\begin{array}{lll}
\mathrm{X}_{1} & \mathrm{X}_{2} & \mathrm{X}_{3}
\end{array}\right] \ldots .(7)
$$

The matrix of Equation 7 may be rewritten as follows:

$$
\begin{gathered}
X_{1}=w_{1}\left(\alpha \sigma_{1}\right)^{2}+w_{2}\left[\left(\alpha \sigma_{2}\right) \rho_{2,1}\left(\alpha \sigma_{1}\right)\right]+w_{3}\left[\left(\alpha \sigma_{3}\right) \rho_{3,1}\left(\alpha \sigma_{1}\right)\right] \\
X_{2}=w_{1}\left[\left(\alpha \sigma_{1}\right) \rho_{1,2}\left(\alpha \sigma_{2}\right)\right]+w_{2}\left(\alpha \sigma_{2}\right)^{2}+w_{3}\left[\left(\alpha \sigma_{3}\right) \rho_{3,2}\left(\alpha \sigma_{2}\right)\right] \\
X_{3}=w_{1}\left[\left(\alpha \sigma_{1}\right) \rho_{1,3}\left(\alpha \sigma_{3}\right)\right]+w_{2}\left[\left(\alpha \sigma_{2}\right) \rho_{2,3}\left(\alpha \sigma_{3}\right)\right]+w_{3}\left(\alpha \sigma_{3}\right)^{2}
\end{gathered}
$$

Next, the matrix of Equation 7 is re-weighted again to get the value of $\mathrm{V}$ as follows:

$$
\left[\begin{array}{lll}
X_{1} & X_{2} & X_{3}
\end{array}\right]\left[\begin{array}{l}
w_{1} \\
w_{2} \\
w_{3}
\end{array}\right]=V
$$

Finally, the Value at Risk ( $\mathrm{VaR})$ is obtained by taking square root of the $\mathrm{V}$-value as in Equation 10.

$$
\operatorname{VaR}=\sqrt{V}
$$

\section{RESULT AND ANALYSIS}

Since the establishment of the first Islamic banks in 1991, the development of the Islamic banking industry in Indonesia continues to growth. Total asset of Islamic bank stood 545,39 trillion rupiah as per June 2020. Though the market share is only $6.18 \%$ to total bank asset in Indonesia, Islamic banks still experience positive growth. The Disbursed Financing (PYD) reached 377,53 trillion rupiah or represents $87.75 \%$ to the third-party fund. It indicates that the intermediation function of Islamic banking is running well. Table 2 shows the profile of Islamic Bank in Indonesia as per June 2020.

Table 2

Profile of Islamic Bank per June 2020

\begin{tabular}{lccccc}
\hline & $\begin{array}{c}\text { Number of } \\
\text { Institutions }\end{array}$ & $\begin{array}{c}\text { Number of } \\
\text { Office }\end{array}$ & $\begin{array}{c}\text { Asset } \\
\text { (trillion Rp) }\end{array}$ & $\begin{array}{c}\text { Disbursed } \\
\text { Financing }\end{array}$ & $\begin{array}{c}\text { Third Party } \\
\text { Fund }\end{array}$ \\
\hline Islamic Commercial Bank & 14 & 1,942 & 356,33 & 232,86 & 293,37 \\
Islamic Business Unit & 20 & 390 & 175,45 & 134,16 & 127,95 \\
Islamic Rural Banks & 162 & 626 & 13,61 & 10,50 & 8,89 \\
\hline Total & 196 & 2,958 & 545,39 & 377,53 & 430,21 \\
\hline
\end{tabular}

Published by University of Airlangga.

This is an open access article under the CC BY license (https://creativecommons.org/licenses/by-nc-sa/4.0/) 
Source: Financial Services Authority (OJK, 2021)

Table 3 presents descriptive statistics of Islamic commercial bank and Islamic business unit bank which is calculated based on 74 months of observations for the period May 2014 to June 2020. In term of financing allocation, the mean value shows debt-based financing still dominates financing product followed by equity and leasebased financing, respectively. The debt-based financing also provides highest rate of return on average by 12.49 percent, followed by equity and lease-based financing by 11.01 and 10.37 percent, respectively.

Table 3

Statistic Descriptive

\begin{tabular}{cccccc}
\hline & Mean & Median & Minimum & Maximum & Std. Dev. \\
\hline Financing Allocation (\%) & & & & & \\
Equity-Based Financing & 39.50 & 38.10 & 31.87 & 49.59 & 6.66 \\
Debt-Based Financing & 56.16 & 58.13 & 47.35 & 62.39 & 5.59 \\
Lease-Based Financing & 4.33 & 3.77 & 3.06 & 5.96 & 1.20 \\
Rate of Return (\%) & & & & 15.48 & 1.79 \\
Equity-Based Financing & 11.01 & 11.08 & 8.48 & 14.87 & 1.01 \\
Debt-Based Financing & 12.49 & 12.17 & 10.87 & 11.16 & 0.52 \\
Lease-Based Financing & 10.37 & 10.52 & 8.35 & &
\end{tabular}

Figure 1 shows more detail trend of financing allocation by type of contract for the observation period. Although the debt-based financing still dominates financing allocation but its trend tends to decrease on average 2.5 percent per year from 63.96 percent in 2014 to 48.94 percent in 2020. In contrast, the equity-based financing tends to increase by $2.93 \%$ from $30.54 \%$ in 2014 to $48.09 \%$ in 2020 . As for lease-based financing, the financing proportion is consistently below 10 percent, however tends to decreased from $5.74 \%$ in 2014 to reach only $3.06 \%$ in 2020 or represent on average 0.42 percent per year. How the debt-based financing dominates the trend complies with the study of Ismal (2010) and Shahri et al. (2015). These findings also indicate a shifting from debt and lease-based financing to the equity-based financing. It implies that Islamic banks are getting closer to the practices of partnership or profit-loss sharing concept that differentiate them from the conventional banking. 


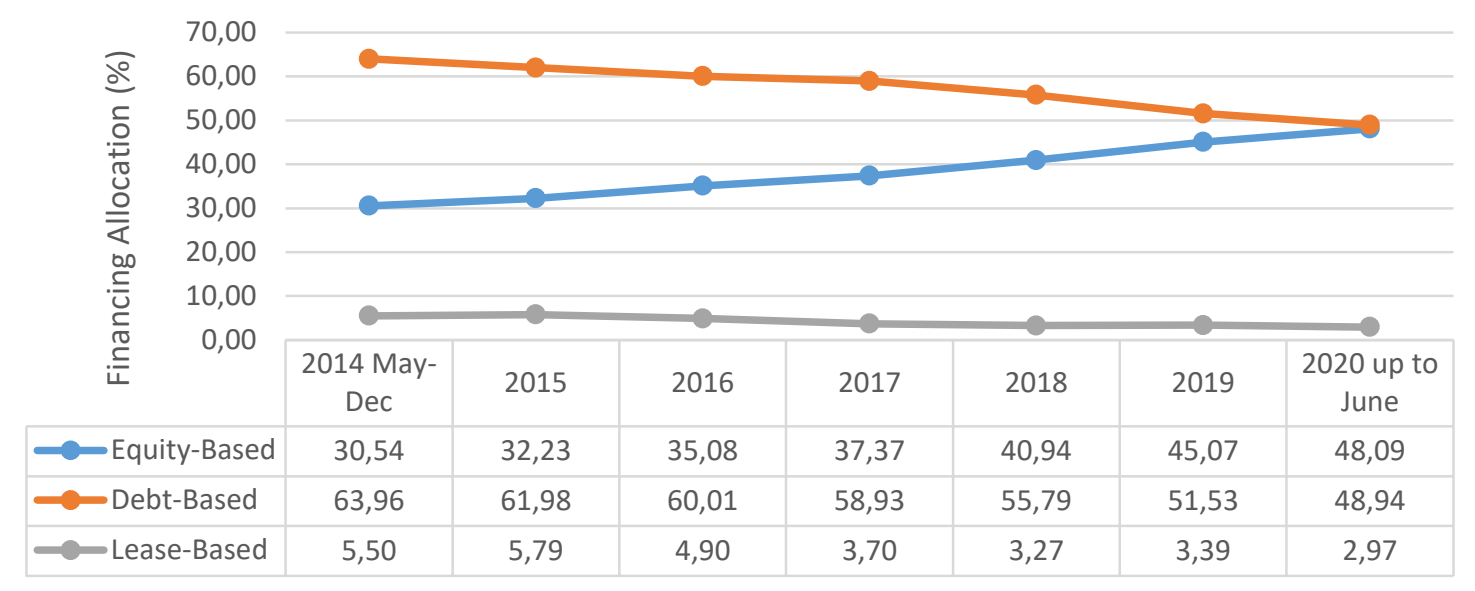

Figure 1. Trend of Financing Allocation by Type of Contract

Source: Data Processed

In contrary to increasing of the equity-based financing allocation, Figure 2 shows that return of such financing asset tends to decline and reach its lowest rate of $8.80 \%$ in 2020 from the highest rate of $15.07 \%$ in 2014 . Similarly, return of the debt-based financing also tend to decrease although still provides higher return than the equitybased financing. Interestingly, the lease-based financing makes relatively stable return even though its financing proportion tends to decrease.

The possible explanation for these phenomena is rate of return very much influenced by market conditions. It is supported by a fact that the central bank's benchmark interest rate has tended to decline from 7.5 percent in 2014 to 4.25 percent in 2017. Although it had risen up to reach 6 percent from mid of 2018 to mid of 2019, but it had gradually declined from the second semester of 2019 to reach only 4 percent in June 2020, based on Bank Indonesia's report in 2020. This market condition affects Islamic banks in determining prices which in turn affect their returns. Therefore, increasing or decreasing asset allocation is not always in line with return obtained. As for the lease-based financing, the stability rate of return was attributed to the long lease financing of heavy equipment rentals to the mining industry (Otoritas Jasa Keuangan, 2018). 


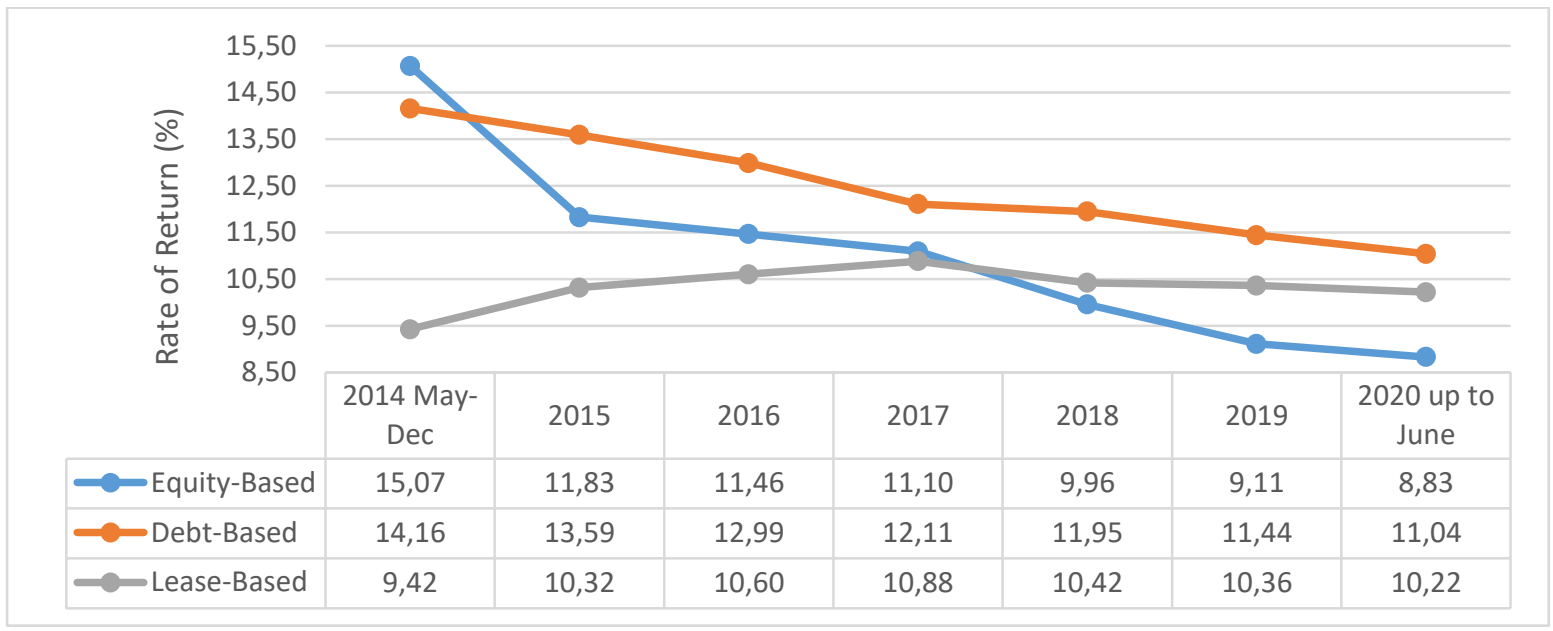

Source: Data Processed

Figure 2. Trend of Financing Return by Type of Contract

The pattern of standard deviation which represents volatility of financing return is presented in Figure 3. The return of equity-based financing is relatively more volatile than the debt-based financing. This finding proves that equity-based financing by nature has high risk due to return are not fixed and fluctuate depend on business performance. An anomaly pattern occurred in the lease-based financing, especially in 2019 and 2020, which tended to increase sharply from 0.31 to 0.89 . A possible reason for this anomaly is increasing uncertainty of non-performing financing (NPF) of ijarah muntahiyah bittamlik (IMBT) contract contributed by financing leases for heavy mining equipment (OJK, 2019). As for increasing volatility in 2020 for all type of contracts, it is expected relate to impact of Covid-19 pandemic.

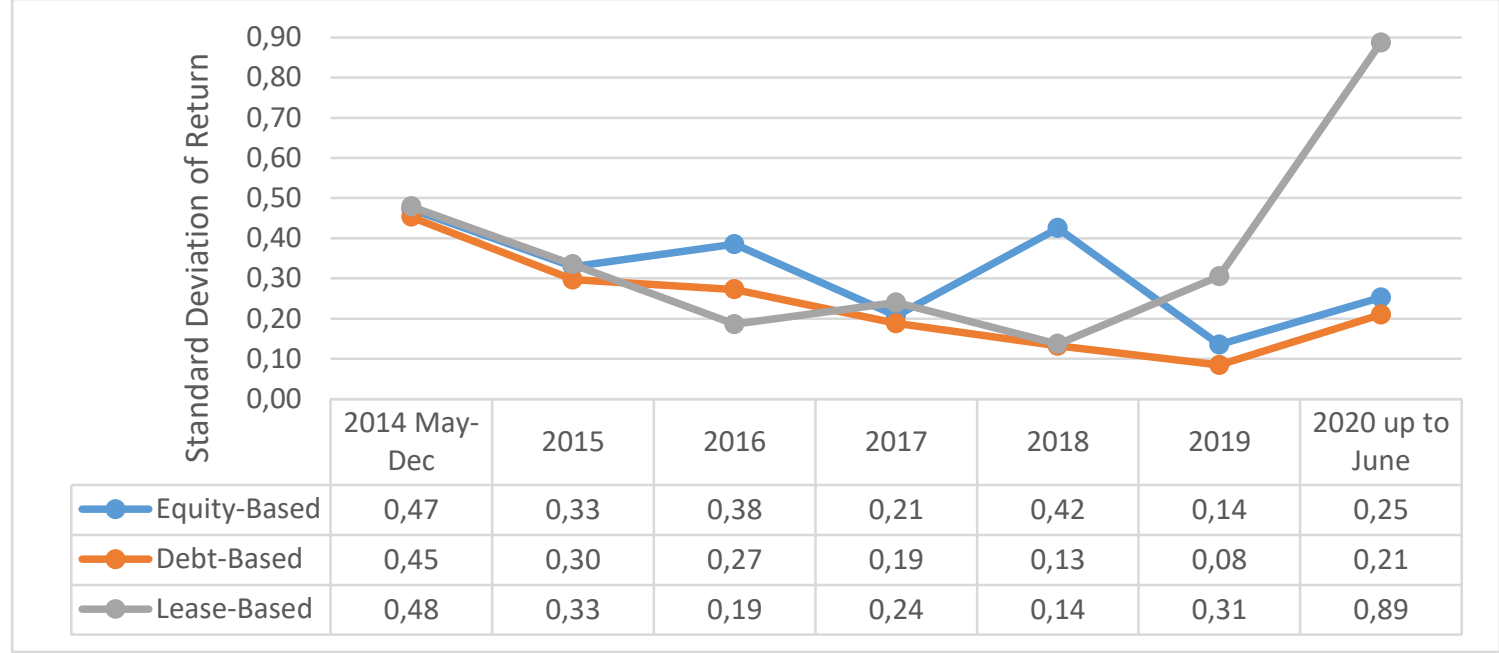

Source: Data Processed

Figure 1. Trend of Standard Deviation by Type of Contract 
The correlation coefficient presented in Table 4 shows mostly positive correlation among type of contract. This finding indicates that the returns tend to move with same direction. This finding also supports the behavior of return that move to follow market benchmark. The negative correlation in some years, especially correlation between equity and lease-based financing in 2014 and 2015, due to the return of equity-based financing has declined sharply compared to other financing types as indicated in Figure 2.

Table 4

Correlation Coefficient among Type of Contract

\begin{tabular}{lccc}
\hline & $\begin{array}{c}\text { Equity and Debt } \\
\text { Based Financing }\end{array}$ & $\begin{array}{c}\text { Equity and Lease } \\
\text { Based Financing }\end{array}$ & $\begin{array}{c}\text { Debt and Lease } \\
\text { Based Financing }\end{array}$ \\
\hline 2014 May-December & 0.14 & -0.28 & 0.54 \\
2015 & -0.35 & -0.57 & 0.77 \\
2016 & 0.58 & 0.13 & -0.62 \\
2017 & 0.86 & 0.79 & 0.69 \\
2018 & 0.95 & 0.87 & 0.88 \\
2019 & 0.64 & 0.41 & 0.46 \\
2020 up to June & 0.38 & -0.35 & 0.37 \\
\hline
\end{tabular}

Source: Data Processed

Figure 4 shows the value at risk that represents risk of financing portfolio for $99 \%, 95 \%$, and $90 \%$ level of confidence, respectively. The financing portfolio risk tends to decrease over the observation period. The lowest risk occurred in 2019. In that year, at the $95 \%$ confidence level there is a 5 percent probability the portfolio return decrease by 0.20 percent. This finding indicates Islamic banks able to reduce the risk of financing portfolio consistently.

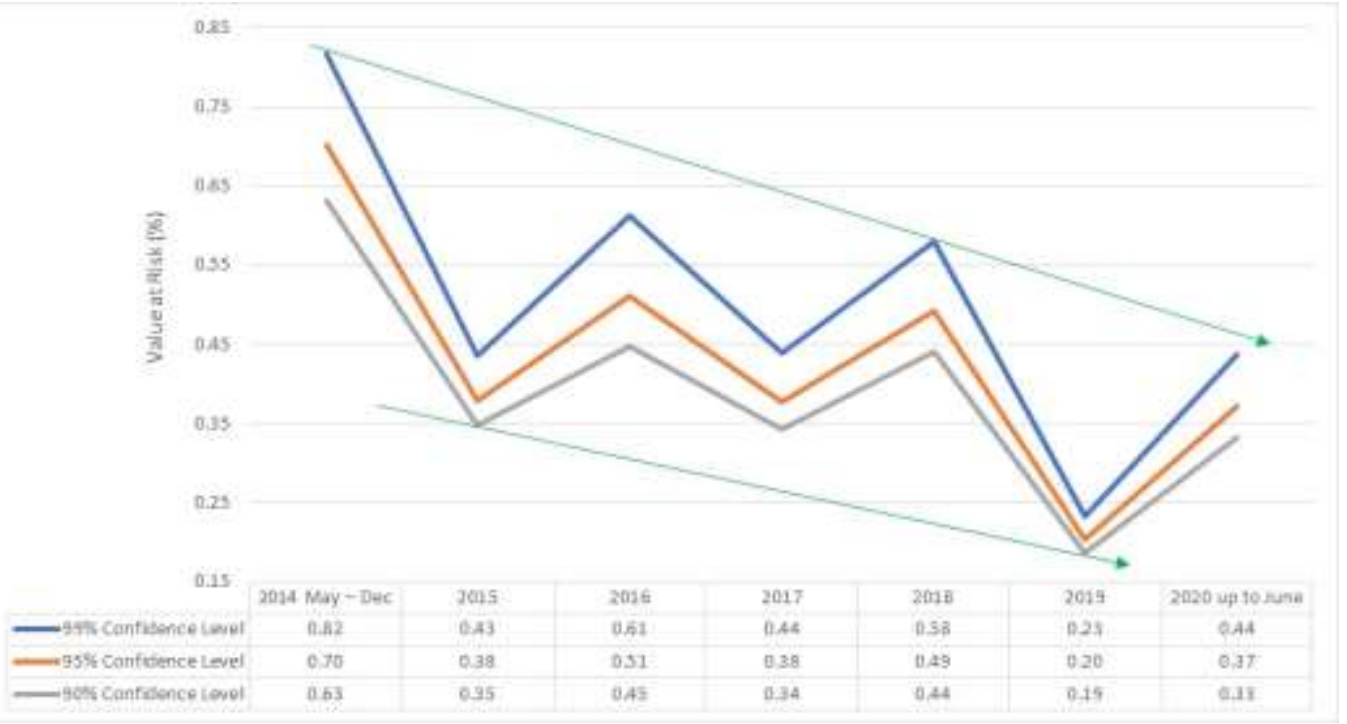

Figure 2. Trend of Value at Risk (VaR)

Source: Data Processed

Published by University of Airlangga.

This is an open access article under the CC BY license (https://creativecommons.org/licenses/by-nc-sa/4.0/) 
Interestingly, the financing portofolio risk shows a unique zigzag pattern. It indicates a learning process of Islamic banks to improve their risk management by apply risk mitigation startegy in a certain period and improve it in the following period, repeatedly. The finding suggests Islamic banks should continue to develop the bestpractice of risk management based on their past experience. As for regulators, the finding may be used as early warning system to anticipate systemic problem in Islamic banking industry if the value at risk tends to approaching unexpected levels.

In the latest development, Covid-19 pandemic has caused unstable growth worldwide. Indonesia experiences negative economic growth in second and third quarter of 2020 by -5.32 and -2.07 percent, respectively as the report from Indonesian Central Bureau of Statistics (Badan Pusat Statistik, 2020). Therefore, the risk of financing portfolio is expected to rise in 2020. Islamic banks are advised to mitigate the effect of Covid-19 pandemic on the financing risk.

\section{CONCLUSION}

This study has achieved the goal of investigating the risk of Islamic bank financing portfolios. Although the debt-based financing still dominates financing portfolio, the study found a shifting financing types into the equity-based contracts. The rate of return tends to decrease over the observation period in which the debt-based financing provides highest return followed by equity and lease-based financing, consecutively. This result may be associated with market rate that tends to decrease as well. Moreover, the pattern of standard deviation suggests the equity-based financing by its nature has higher risk compared to other financing types.

The result of value at risk shows a unique downward-sloping zigzag pattern which indicates the ability of Islamic banks to improve their risk management. However, the risk related Covid-19 pandemic need to be mitigated properly to prevent the increasing of financing risk. It is suggested for Islamic banks to continue seek the best-practice of risk management based on their past experience. The regulators may use the finding to develop early warning system to anticipate a systemic failure in Islamic banking industry. Since the financing portfolio risk closely related to market risk, further research is encouraged to investigate impact of market behaviour on the risk of each type of financing.

\section{ACKNOWLEDGMENT}

Alhamdulillah, because of His Greatness this study could be done successfully. Also, a grateful acknowledgment we present for our dearest parents, families, friends, and colleagues. We sincerely thank for your supports and prayers. We would like to 
thank JEBIS editorial team; editor in chief, reviewer, editor, and all team included, for the advice and suggestion to make this article proper for publication.

\section{REFERENCES}

Ahmad, N. H., \& Ahmad, S. N. (2004). Key Factors Influencing Credit Risk of Islamic Bank: a Malaysian Case. Journal of Muamalat and Islamic Finance Research (JMIFR), 1(1). http://ddms.usim.edu.my/handle/123456789/5298

Akram, H., \& Rahman, K. ur. (2018). Credit Risk Management: A Comparative Study of Islamic Banks and Conventional Banks in Pakistan. ISRA International Journal of Islamic Finance, 10(2), 185-205. https://doi.org/10.1108/IJIF-09-2017-0030

Al-Foul, L. R. A. (2017). Forecasting Asset Covariances and Variances based on MultiScale Risk Models on Portofolio Optimization Evidence from Amman Stock Exchange (ASE) [Yarmouk University]. http://repository.yu.edu.jo/bitstream/123456789/14083/1/675115.pdf

Badan Pusat Statistik. (2020). Analisis Hasil Survei Dampak Covid-19 terhadap Pelaku Usaha.

https://www.bps.go.id/publication/2020/09/15/9efe2fbda7d674c09ffd0978/anal isis-hasil-survei-dampak-covid-19-terhadap-pelaku-usaha.html

Butler, C. (1999). Mastering Value at Risk: A Step-by-step Guide to Understanding and Applying VaR. Financial Times/Prentice Hall.

Chamberlain, T., Hidayat, S., \& Khokhar, A. R. (2020). Credit Risk in Islamic Banking: Eidence from the GCC. Journal of Islamic Accounting and Business Research, 11(5), 1055-1081. https://doi.org/10.1108/JIABR-09-2017-0133

Chowdhury, M. A. F., Shoyeb, M., Akbar, C., \& Islam, M. N. (2016). Risk Sharing Paradigm of Islamic Banks: Case of Bangladesh. In D. S. Mutum, M. M. Butt, \& M. Rashid (Eds.), Advances in Islamic Finance, Marketing, and Management (pp. 103-130). Emerald Group Publishing Limited. https://doi.org/10.1108/978-1-78635-899820161007

Dewi, V. I. (2013). Asset Allocation: Diversification dan Rebalancing sebagai Bagian dari Proses Perencanaan Keuangan (Suatu Kajian Pustaka). Bina Ekonomi, 17(1). https://doi.org/10.26593/be.v17i1.805.\%25p

Errico, L., \& Sundararajan, V. (2002). Islamic Financial Institutions and Products in the Global Financial System: Key Issues in Risk Management and Challenges Ahead (02/192). https://papers.ssrn.com/sol3/papers.cfm?abstract_id=1930788

Fakhfekh, M., Hachicha, N., Jawadi, F., Selmi, N., \& Cheffou, A. I. (2016). Measuring Volatility Persistence for Conventional and Islamic Banks: An FI-EGARCH Approach. Emerging Markets Review, 27(June 2016), 84-99. https://doi.org/10.1016/j.ememar.2016.03.004

Ferhi, A. (2018). Credit Risk and Banking Stability: A Comparative Study between Islamic and Conventional Banks. International Journal of Law and Management, 60(4), 1009-1019. https://doi.org/10.1108/IJLMA-05-2017-0112

Grassa, R. (2012). Islamic Banks' Income Structure and Risk: Evidence from GCC 
Countries. Accounting Research Journal, 25(3), 227-241. https://doi.org/10.1108/10309611211290185

Hanif, M. (2016). Economic Substance or Legal Form: An Evaluation of Islamic Finance Practice. Iternational Journal of Islamic and Middle Eastern Finance and Management, 9(2), 277-295. https://doi.org/10.1108/IMEFM-07-2014-0078

Haron, A., \& Hock, J. L. H. (2012). Inherent Risk: Credit and Market Risks. In S. Archer \& R. A. A. Karim (Eds.), Islamic Finance: The Regulatory Challenge (pp. 94-120). Wiley. https://doi.org/10.1002/9781118390443.ch5

Ikatan Bankir Indonesia. (2018). Memahami Bisnis Bank Syariah. Gramedia Pustaka Utama.

Iqbal, Z., \& Mirakhor, A. (2011). An Introduction to Islamic Finance: Theory and Practice. John Wiley and Sons.

Ismal, R. (2010). Volatility of the Returns and Expected Losses of Islamic Bank Financing. International Journal of Islamic and Middle Eastern Finance and Management, 3(3), 267-279. https://doi.org/10.1108/17538391011072453

Ismal, R. (2014). An optimal risk - return portfolio of Islamic banks. Humanomics, 30(4), 286-303. https://doi.org/10.1108/H-08-2013-0055

Kabir, M. N., Worthington, A., \& Gupta, R. (2015). Comparative Credit Risk in Islamic and Conventional Bank. Pacific-Basin Finance Journal, 34(September), 327-353. https://doi.org/10.1016/j.pacfin.2015.06.001

Louhichi, A., \& Boujelbene, Y. (2016). Credit Risk, Managerial Behaviour and Macroeconomic Equilibrium within Dual Banking Systems: Interest-Free vs. Interest-Based Banking Industries. Research in International Business and Finance, 38(September), 104-121. https://doi.org/10.1016/j.ribaf.2016.03.014

Masood, O., Al-Suwaidi, H., \& Thapa, P. D. P. (2012). Credit Risk Management: A Case Differentiating Islamic and Non-Islamic Banks in UAE. Qualitative Research in Financial Markets, 4(2/3), 197-205. https://doi.org/10.1108/17554171211252529

Mokni, R. B. S., Rajhi, M. T., \& Rachdi, H. (2016). Bank Risk-taking in the MENA Region: A Comparison between Islamic Banks and Conventional Banks. International Journal of Social Economics, 43(12), 1367-1385. https://doi.org/10.1108/IJSE-032015-0050

Obaidullah, M. (2005). Islamic Financial Services (1st ed.). Scientific Publishing Centre King Abdulaziz University.

Otoritas Jasa Keuangan. (2018). Statistik Perbankan Syariah - Desemer 2017. https://www.ojk.go.id/id/kanal/syariah/data-dan-statistik/statistik-perbankansyariah/Pages/Statistik-Perbankan-Syariah---Desember-2017.aspx

Otoritas Jasa Keuangan. (2021). Statistik Perbankan Syariah - Desember 2020. https://www.ojk.go.id/id/kanal/syariah/data-dan-statistik/statistik-perbankansyariah/Pages/Statistik-Perbankan-Syariah---Desember-2020.aspx

Rosly, S. A., \& Zaini, M. A. M. (2008). Risk-return Analysis of Islamic Banks' Investment Deposits and Shareholders' Fund. Managerial Finance, 34(10), 695-707. https://doi.org/10.1108/03074350810891010 
Sari, A. P. N., \& Purwanto, A. (2012). Analisis Kebijakan Alokasi Aset, Kinerja Manajer Investasi dan Tingkat Risiko terhadap Kinerja Reksadana Saham di Indonesia [Diponegoro University]. http://eprints.undip.ac.id/36200/

Shahari, F., Zakaria, R. H., \& Rahman, M. S. (2015). Investigation of the Expected Loss of Sharia Credit Instruments in Global Islamic Banks. International Journal of Managerial Finance, 11(4), 503-512. https://doi.org/10.1108/IJMF-12-2014-0196

Tan, T.-K., \& Lakehal-Ayat, M. (2018). A Big Data Bayesian Approach to Earnings Profitability in the S\&P 500. PSU Research Review, 2(1), 35-58. https://doi.org/10.1108/PRR-04-2017-0023

Tariqullah, K., \& Habib, A. (2001). Risk Management: An Analysis of Issues in Islamic Financial Industry (Occasional Papers). Occasional Papers. https://ideas.repec.org/p/ris/irtiop/0091.html

Warninda, T. D., Rofikoh, R., \& Ekaputra, I. A. (2019). Islamic Bank Profit-Loss Sharing Financing and Earnings Volatility. Social Sciences and Humanities, 27(S2), 229239. 